\title{
Transparency Principle on Land Acquisition for Agrarian Justice
}

\author{
Rosmidah ${ }^{\star}$; Dony Yusra Pebrianto ${ }^{\star \star}$ \\ Faculty of Law Universitas Jambi-Indonesia \\ *rose_andy64@yahoo.co.id

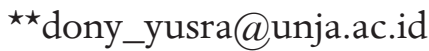

\begin{abstract}
The purpose of this article is to study the state's efforts to guarantee the principle of transparency and implement it into land acquisition process for the sake of public interest. With normative method, this article found that the land, despite of being an object of private ownership, has a social function. Therefore, the state has an authority to regulate the utilisation and use of land for the sake of public interests through a land acquisition. In recent years, disputes due to land acquisition between the government and the land owners has always increased, resulting in the use of violence and public distrust against the government. It is believed that such the condition was triggered by the lack of transparency as long as the land acquisitions are concerned. In order to realize agrarian justice, which is the state's obligation, it is necessary to guarantee the principle of transparency in the land acquisition process which are the basic rights of land owners / holders and the general public. Because the principles of openness and transparency in the Land Acquisition Law are obscure in norms, it is necessary to interpret the law. The principles of openness and transparency are carried out from the planning, preparation, implementation stages to the stage of submitting the results of land acquisition. At the empirical level, it must be implemented without causing various encapsulation resulting in land acquisition disputes. The principles of openness and transparency are needed to facilitate the flow of community participation in development.
\end{abstract}


Keywords: Agrarian Justice; Land Acquisition; Principle of Transparency

\section{A. Introduction}

Land is always important to manage activities of the nation and state. Not only is the land used as a residential area, it is also an object for infrastructure development such as building construction, toll roads, and reservoirs. Various buildings are erected on the ground so that the surface of the earth has a value that can be measured in money because it can be bought and sold or rented. Ismaya firmly stated, "apart from economic value, land also has a functional value as a unifying tool. This is illustrated by the benefits of land as a shared residence in certain areas, so that there is a link between the land and the people who occupy it."

The development of land law in Indonesia is emphasized in the Article 33 paragraph (3) of the 1945 Constitution, which in essence is that all natural resources that meet the livelihoods of many people, including land, by the government must be managed for the realization of a just, prosperous and prosperous Indonesian people." Efforts to realize the purpose of Article 33 paragraph (3) of the 1945 Constitution by the government formed a regulation which can be used as a basis for making land natural resources as a medium for achieving prosperity.

The regulation referred to in the meaning of Article 33 paragraph (3) of the 1945 Constitution is Law Number 5 of 1960 on Basic Agrarian Law (hereinafter reffered to as UUPA). The enactment of the UUPA is intended as a guideline that spells out the objectives of Article 33 paragraph (3) of the 1945 Constitution and as the implementer is given authority to the state as the right holder, namely "the right to controll by the State" as referred to in Article 2 paragraph (2) of the UUPA." Article 2 of UUPA regulates that the State as an organization of power of the highest people is given the authority to regulate, organize, determine and supervise the designation, owner-

1 Samun Ismaya, Hukum Administrasi Pertanahan (Land Administration Law), Yogyakarta, Graha Ilmu, 2013, p. 35. 
ship, use, exploitation and maintenance of agrarian resources in the form of land, water, natural resources contained therein and outer space within certain limits regulated in laws and regulations.

One of the general policy directions for national development 2020-2024 is to strengthen infrastructure to support economic development and basic services. One of the infrastructure needs is the availability of land. Land and development is two inseparable units. Apart from having economic value, land also has a social function, in the sense that it does not only function for the land owner, but also for the Indonesian nation as a whole. As the consequence, the use of land should not only be guided by the interests of the rights' holders, but it shall take into account the interests of the community as well. This shows that land has a dual function, both as social and economical asset."2

To bring Article 6 of the UUPA into effect, various regulations related to land acquisition and public interests have been issued. There are at least 5 (five) regulations that have been and are currently put into effect: (1) Law Number 20 of 1961 on Revocation of Rights to Land and Objects Above It; (2) Regulation of the Minister of Home Affairs Number 15 of 1975 on the Procedures of Land Acquisition, (3) Presidential Decree of the Republic of Indonesia Number 55 of 1993 on Land Acquisition for the Implementation of Development for Public Interest, (4) Presidential Regulation of the Republic of Indonesia Number 36 of 2005 on Land Acquisition for Implementation of Development for Public Interest and (6) Law Number 2 of 2012 on Land Acquisition for Development for Public Interest (Land Acquisition Law).

The existence of the Land Acquisition Law brings major changes development in Indonesia, especially in the reformation of national land law. These changes, according to Oloan Sitorus s are:

(1) establish 4 stages which provide clarity of the party responsible for

2 Muhammad Yusrizal, "Perlindungan Hukum Pemegang Hak Atas Tanah dalam Pengadaan Tanah Untuk Kepentingan Umum” (Legal Protection of Land Rights Holders in Land Acquisition for Public Interest), Jurnal De Lega Lata, Volume 2 Number 1, January-June, 2017, p. 114. 
each stage, the measurable output of each activity in each stage, and clear implementation time; (2) define deliberation as the basic principle of land acquisition, so that there is legal equality between land owners and those who need land; (3) participatory in the sense of a. there is space for community involvement in every stage of implementation, b. guarantee that the public will have access to information on development plans carried out by the Government, c. determination of the construction location is based on the agreement of the land owner community. (4) closing the opportunity for the government to intervene in determining the amount of compensation; (5) guarantees the right to object at the level of determining the construction location and determining the amount of compensation; (6) making the judiciary body the final decision maker for the construction location and the amount of compensation. ${ }^{3}$

The implementation of land acquisition often creates conflicts of interest between the government and land owners. Yet, "land Acquisition for Public Interest is aimed at providing land for the implementation of development in order to improve the welfare and prosperity of the nation, state and society while maintaining the legal interests of the Entitled Party."4

Esssentially, the state is obliged to develop the standard of living of its citizens. Whilest, in the same time, it shall not violate the rights of citizens when the development is carried out. Citizens have the right to be involved in every development process and the State shall accommodate such right. In relation to land acquisition, Maria SW Sumardjono argue that there are three important things to be accommodated: "1.Respect and protection of human rights in the form of poverty alleviation, expansion of employment, and equitable development; 2 . The sustainability of the people's productive capacity; 3.Community empowerment through the development and implementation of good governance (participation, transparency, accountability, and the rule of

3 Oloan Sitorus, Pengadaan tanah Untuk Pembangunan Bagi Kepentingan Umum (Permasalahan dan Alternatif Solusi) (Land Acquisition for Development in Public Interest (Pproblems and Alternative Solutions)), Proceeding of National Seminar on Problematika Pertanahan dan strategi penyelesaiannya (Problems on Land and Its Resolutions), Cooperation between STPN Faculty of Law Trisakti University, Jakarta, 7 October 2017, p. 29.

4 Article 3 Law No. 2/2012 on Land Acquisition. 
law).",

However, the conflicts related to land acquisition are still big in numbers. Throughout 2017, the Consortium for Agrarian Reform (KPA) recorded that there are at least 659 agrarian conflicts with an area of 520,491.87 hectares. Meanwhile, according to the Indonesian Legal Aid Foundation (YLBHI), 300 cases of agrarian conflicts were occurred in 16 provinces in 2018. Most of these cases were dominated by land acquisition cases for infrastructure needs. The conflicts rising during the development, such as ones reconstructions of International Airport in West Java and Yogyakarta illustrate the conventionality in acquiring the land. ${ }^{6}$

According to KPA, those conflicts were triggered by: (1) lack of public participation; (2) unfavorable price fixing; (3) Corruption and extortion in land acquisition: (4) the involvement of officers and the reduce of price due to high cost in the process of land acquisition; (5) Various alternative options were offered to landowners and agreed by both parties, but were not implemented by the government.. These problems have occured due to lack of principle of transparency by the government. In fact, the parties who hold the right over the land view that government tends not to convey the information and plan as long as the development is concerned, yet the community should have access to any information related to land acquisition and government's plan. Due to the complexity of such issues, this article discusses on how the state guarantee the principle of transparency during the acquisition of the land and how to apply the principle in the process of acquiring the land for the sake of public interest.

5 Maria SW Sumardjono, Tanah Dalam Perspektif Hak ekonomi Sosial dan Budaya (Land in the Economic, Social and Cultural Rights Perspective), Penerbit Buku Kompas, Jakarta, 2008, p. 271.

6 Konsorsium Pembaruan Agraria (KPA), Catatan Akhir Tahun 2017: Reformasi Agraria di Bawah Bayangan Investasi (End Note Year 2017: Agrarian Reform Under the Shadow of Investment), 2017, p. 10

7 Ibid., p. 10. 


\section{B. Land Acquisition for the Development of Indonesia}

Juridically, the term "land acquisition" was first known since the issuance of Presidential Decree of the Republic of Indonesia Number 55 of 1993 on Land Acquisition for the Implementation of Development for Public Interest. According to Article 1, land acquisition is defined as "any activity to acquire land by giving compensation to those entitled to the land." Since land acquisition is a legal act by the government with a public perspective, land acquisition is principally aimed to the public interests. Thus, in every provision regarding land acquisition, development for the sake of public interest is always emphasized. According to the General Explanation of the LoGA, one of the development efforts within the framework of national development organized by the government is development for the public interest. It requires land in which is acquired by prioritizing the principles contained in the 1945 Constitution of the Republic of Indonesia and the national land law.

The latest regulation regarding land acquisition is the issuance of Law No. 2 of 2012 (hereinafter referred to as the Acquisition Law). However, the existence of this regulation has not been able to reduce the conflicts indicated by the emergence of various problems in every land acquisition project for development for the public interest. Various tensions arise within the community due to disagreements between land owners/rights holders and the authorities in charge.

In addition the conflict and tension, another problem is the status of land rights, especially lands controlled according to customary law, owners/holders of communal rights which becomes an excuse for the government in granting the form and amount of compensation to be given to affected communities. Mahendra suggests, all these problems arise from discrepancy between public and private interests in the development. ${ }^{8}$ The public interest is an objective that the government wants to fulfill in land acqui-

8 A.A. Oka Mahendra, Menguak Masalah Hukum, Demokrasi dan Pertanahan (Uncovering Legal, Democracy and Land Problems), Sinar Harapan, Cet Pertama, Jakarta, 1996 , p. 256. 
sition and is a reason to give the state the authority to take over land rights owned by the community and the customary rights of indigenous peoples. The interpetation of the public interest becomes the main concern in land acquisition. "dissent interpreation on public interest between the Government and owners of land, either building or planting rights, may lead to behavior or attitudes ending up to disputes on land acquisition for public interests. ${ }^{9}$

In Indonesia, the definition of public interest is regulated in the Land Acquisition Law as the interests of the nation, state and society that must be realized by the government and used as much as possible for the welfare of the people. The characteristics of public interest activities carried out as non-profit by the government, both central and local. Such activities are classified into 18 types of activities. Such elaboration in fact obscures the meaning of the public interest and has eliminated the right of citizens to determine the type of development in the public interest, as some activities raise the question of whether it is worthy of being called the public interest, railway, international general hospital, iInternational airport, which are only enjoyed by a limited part of society.

According to Jeany, there has been a shift in the concept of general importance in land acquisition regulations in Indonesia. This implicates shifting the concept of public interest which emphasizes the common interest, but in its implementation emphasizes the interests of individuals or groups. ${ }^{10}$

Initially the concept of public interest included projects carried out by the private sector for the benefit of the Dutch colonial govern-

9 Yanto Sufriadi, Rekonstruksi Penyelesaian Sengketa Pengadaan Tanah Untuk Kepentingan Umum Dalam Perspektif Hukum Progresif (Reconstruction of Land Acquisition Dispute Resolution for Public Interest from a Progressive Legal Perspective), Doctoral Thesis, Program Doktor Ilmu Hukum Univ. Diponegoro, Semarang, 2011, p. 286.

10 Tabitha Sri Jeany, Pergeseran Konsep Kepentingan Umum dan Implikasinya Dalam Pengadaan Tanah di Indonesia (Shifting Concepts of Public Interest and Its Implications in Land Acquisition in Indonesia), Doctoral Thesis, Program Doktor Ilmu Hukum Univ Islam Indonesia, Yogyakarta, 2017, p. 327. 
ment. The issuance of the UUPA as a legal unification in the agrarian sector at the same time enlightens the public interest as a manifestation of the social function of land. The definition of public interest is interpreted broadly and there are types and lists of activities of public interest. However, in the following regulations there was a shift due to the entry of private parties. Although constitutionally there is no ammendment, the implementation of the concept of public interest has changed as a result of the different visions, missions, policies and government programs in each period.

As in Indonesia, in Malaysia the concept of public interest has also changed. The 1961 Land Acquisition Deed (APT) does not provide an understanding of common interests. APT only provides general guidance (general guide). The definition of the intention and purpose of the public interest is to see whether the purpose or objective is to provide public interests to the public or vice versa. On September 12, 1991 there was a change in the concept of land acquisition. Previously, land was taken for the purpose of the public, but now land can be taken for individuals to carry out economic activities for personal, corporate or corporate purposes.

In the implementation of land acquisition, there are various factors that influence the implementation of development, which are internal and external factors. Internal factors concern with land acquisition for the sake of development, namely from the government and the community. The external factors concern with factors influencing the process of land acquisition for the public interest which commonly arise from the community holding land rights which. ${ }^{11}$

\section{Principles of Land Acquisition for Development}

Land acquisition for development in Indonesia is based on the main principle for the public interest. Development for the public interest is carried out in order to create a just and prosperous society based

11 Sahman, at. El, Permasalahan Hukum Pembebasan Tanah Untuk Kepentingan Pembangunan di Kab. Lombok Utara" (Legal Issues on Land Acquisition for Development in North Lombok Regency), Paper presented in a seminar, Cooperation of Pusrema and Bappeda KLU, 2012, p. 126 
on Pancasila and the 1945 Constitution, meaning that land acquisition is carried out by prioritizing the principles of humanity, democracy and justice. Therefore, the government has the constitutional authority to take land from parties entitled for development on the basis of the State's Right to Control (HMN) as confirmed in Article 33 paragraph (3) of the 1945 Constitution in conjunction with Article 2 of the UUPA.

Nevertheles, the control by the state is used for the greatest prosperity of the people. In another part of the 1945 Constitution emphasizes respect for private property, as confirmed in Article 28 A, $28 \mathrm{H}$ paragraph (4) and Article $28 \mathrm{~J}$ paragraph (2). Everyone has the right to live and has the right to defend his life and life. Everyone has the right to own private property and these rights cannot be taken over arbitrarily by anyone. In exercising his right to freedom, everyone is obliged to comply with the restrictions imposed by law with the sole purpose of guaranteeing recognition and respect for the rights and freedoms of others and to fulfill just demands in accordance with considerations of moral, religious values, security, and public order in a democratic society.

According to Wahanisa, based on the concept of a rule of law, a welfare state and restrictions on the use of rights to control from the state, in connection with the acquisition of rights over land, two things constitute important limitations, namely that land acquisition is carried out solely for the sake of public interest and that rights holders must be compensated". ${ }^{12}$

The authority to take land for the implementation of development in the public interest is basically universal. The principles underlying the land acquisition by the government refer to the principle: salus papule est suprema lax (people's welfare is the highest law), necessity publica major est quam privata (public interest is greater

12 Rofi Wahanisa, Politik Hukum Pengaturan Pengadaan Tanah Bagi Pembangunan Untuk Kepentingan Umum (Legal Politics of Land Acquisition Arrangements for Development for Public Interest), Proceeding of $\mathrm{Na}$ tional Seminar, Cooperation between STPN and Pusat Studi Hukum Agraria, Jakarta 7 Ocktober 2017. 
than private interest), princeps et respublica ex justa causa possunt rem meam auferre (the prince and the commonwealth, for a just cause, can take away my property), the ruler and the state, with reasonable / adequate reasons, can take over personal interests), the law imposed on every subject that he prefers the urgent service of his Prince and Country, before the safety of his life (the law requires a person to prioritize the interests of the state over personal safety). ${ }^{13}$ Sumardjono stated that responsibility of land acquisition requires good faith of all parties, and for the implementers it is a difficult task, especially because what is at stake is a sense of justice that lives in the heart of every human being. ${ }^{14}$

The Law No. 2 / 2012 concerning Land Acquisition, Article 3, states that; "Land acquisition for public purposes aims to provide land for the implementation of development in order to increase the welfare and prosperity of the nation, state and society while still ensuring the legal interests of the entitled parties." Despite the priority of the public interest, however, the interests of the community as individuals must also be respected because every individual has the right to receive fair and proper treatment before the law as referred to in the provisions of Article 3 of Law Number 39 Year 1999 concerning Human Rights which contains provisions that "Everyone has the right to recognition, guarantees, protection, and fair legal treatment and to receive legal certainty and equal treatment before the law."15

Land acquisition for public interest is carried out in accordance with: 1) Regional Spatial Planning; 2) National / Regional Development Plans; 3) Strategic Plan; 4) Work plan of every

13 Om Prakash Anggarlawa, Compulsory Acquisition of Land In India Commentary On The Acquisition of Land Act, I of 1894, New Delhi India: The University Book Agency, 1993, p. 16-17.

14 Maria S.W. Sumardjono, Kebijakan Pertanahan, Antara Regulasi dan Implementasi (Land Policy, Between Regulation and Implementation), Jakarta: Penerbit Buku Kompas, 2009, p. 266.

15 Sahnan, et.all., "Penerapan Prinsip Keadilan Dalam Pembebasan Tanah Bagi Pembangunan Untuk Kepentingan Umum” (Application of the Principle of Justice in Land Acquisition for Development for Public Interest), Jurnal IUS, Vol. III No. 9, December 2015, p. 423. 
agency requiring land. If land acquisition is carried out for road infrastructure such as inter-provincial toll roads, the procurement will be carried out based on the Strategic Plan and Work Plan of the agency requiring land, in this case the Ministry of Public Works and Public Housing. Land acquisition for the public interest is carried out through planning involving all stakeholders and stakeholders as in Article 7 of the Land Acquisition Law.

Article 2 of the Land Acquisition Law stipulates 10 principles / principles of land acquisition for development, namely the principles of humanity, justice, benefit, certainty, openness, agreement, participation, welfare, sustainability and harmony. In its implementation, the principles of land acquisition must be in accordance with the values of the life of the nation and state, therefore the government must make clear rules accompanied by good supervision to realize these principles.

Principles, in a legal context, are formulated as something behind legal norms providing direction on what should be done, contained in an article / paragraph, are general, objective, and logical. Its duty is to resolve conflict of norms within a certain legal system, so that harmonization and synchronization may be realized. ${ }^{16}$ The principles of land acquisition become legal basis for government action in implementing concrete land acquisition regulations, meaning that the legal principles of land acquisition function as means for legal regulations to bridge positive law with legal ideals, yet the principles have to be described in legal norms.

\section{Principles of Transparency of Land Acquisition to Achieve Agrarian Justice}

A fair and populist land policy, normatively, has been outlined in the UUPA, as stated in Articles 2, 3, 5, 6, 7, 10 and 17 of the UUPA. However, at the empirical level, these provisions are not well implemented as the political choice of law fails to support the values of justice

16 Soedikno Mertokoesoemo, Mengenal Hukum (Understanding the Law), Yogyakarta: Liberty, 1985, p. 31-34. 
and populism, and resulting in unjustice in agrarian affairs. The existence of regulations on natural resources and the implementation of regulations for the UUPA are believed to be pro-capitalist. Despite the lateness might be, it is time for the legal structure to restructure control, ownership, use and utilization of land and natural resources through agrarian reform programs that enables justice to be brought about.

One of ways to implement agrarian justice is providing opportunities for the community to get informed related to land acquisition. According to the Elucidation of Article 2 of the Land Acquisition Law, what is meant by the principle of transparancy is that land acquisition for development is carried out by providing access to the public to obtain information related to land acquisition. The principle of transparancy is meant to urge the state guarantee access or freedom for everyone to obtain information about the implementation of land acquisition for development in the public interest, namely information on the stages of planning, preparation, implementation and delivery of the results of land acquisition. Transparency is also meant that open policy is implemented for monitoring every aspect of government policies accessible to all levels of society. Access to information is urgent that the land acquisition process based on the preferences of the land-holding community will not lead to conflicts in the form of violence or intimidation.

The right to information related to land acquisition is an important and strategic right for the community, especially land owners / holders to get access to information on other rights, namely convenience of the process, justice, participation in development, and fair and appropriate compensation as a result of land acquisition withhout which fair and reasonable compensation will not be achieved.

The right to obtain information is not only guaranteed in international agreements but is also affirmed in the constitution, namely in Article 28F of the 1945 Constitution. The existence of human rights in the constitution demonstrates a transformation of human rights from moral rights to legal rights. Since 1946 the General Assembly of the United Nations has adopted Resolution 59 (1) which 
states that freedom of information is a fundamental human right and is a sign of all freedoms which will be the focus of the UN". ${ }^{17}$ Therefore, the right to information has become one of the rights that are recognized internationally, which is regulated in Article 19 of the United Nations Universal Declaration of Human Rights which states that: "Everyone has the right to freedom of expression and ideas, this right includes the right to hold opinions without interference. hands, and seek, receive and disseminate information and ideas through any media regardless of national boundaries."

Indonesia has recognized the right to information as stipulated in the Second Amendment of the 1945 Constitution Article 28F which states that: "Everyone has the right to communicate and obtain information to develop their personal and social environment, as well as the right to seek, obtain, possess and store information with use all available channels." It is learnt, therefore, that the right to information is not only a human right but also a constitutional right of the Indonesian people. The essence of this recognition is that the right to information is actually a right inherent in every human being, both as a citizen and as a person. ${ }^{18}$

The right to information has been stated in the Law No. 14 of 2008 concerning Freedom of Information (UU KIP). The existence of UU KIP becomes the operational basis for the government in carrying out development to provide information and guarantee public access to information, in this case, the land acquisition process for development for the public interest.

Regulations related to land acquisition must be communicated to the community, especially land owners / holders, regarding the purpose of land use, the amount of compensation and procedures for paying compensation and the entire land acquisition administrative process. The delivery of information regarding land acquisition

17 Toby Mendel, Freedom of information as An Internatonally Protected Human Right, Article 19 (www.article 19.org).

18 Nunuk Febriananingsih, "Keterbukaan Informasi Publik Dalam Pemerintahan Menuju Tata Pemerintahan Yang Baik” (Public Information Openess in Governance Towards Good Governance), Jurnal Rechtsvinding, Vol I Nomor I, April 2012, p. 135. 
plans for the public interest can be done through legal counseling and accessible information media. The information provided starts from the planning stage to the delivery of results and is not sectoral but comprehensive in nature related to land acquisition.

Transparancy of information regarding land acquisition is very important for the government, the general public and especially land owners, because: first, information is a basic need of everyone, especially of land owners in the context of personal development and their social environment and is an important part of national security; second, the right to obtain information is a human right and the openness of public information is one of the important features of a democratic country which upholds the sovereignty of the people in realizing good state administration; third, openness of public information is a mean of optimizing public supervision of the state administration and other public bodies and anything that results in the public interest; fourth, the management of public information is an effort to develop an informative society. ${ }^{19}$

The emergence of various disputes due to land acquisition for development in the public interest, one of which is because the community fail to get complete and clear information regarding the land acquisition project, especially the purpose of the land acquisition project, the meaning of the public interest, fair and proper compensation, as well as project benefits for land owners . The government's openness can be seen when there are officers taking measurements and various news related to the development of the public interest in a location.

The importance of the principle of transparency in the land acquisition process for the public interest that:

1. Openness enables land owner / community access to various sources of information related to land acquisition. This can make the community have a clear understanding of various matters

19 Eko Noer Kristiyanto, "Urgensi Keterbukaan Informasi Dalam Penyelenggaraan Pelayanan Publik" (The Urgency of Information Disclosure in Public Service Delivery), Jurnal Penelitian Hukum De Jure, Akreditasi LIPI: No:740/ AU/P2MI-LIPI/04/2016, p. 233. 
relating to governance and in turn the community is able to actively participate in influencing the public agenda. Openness is an absolute prerequisite for constructive and rational participation by communities / landowners

2. The basis for the administration of government in democratic countries is from the people, by the people, and for the people. The existence of government in a democratic country must be understood that as the party elected by the people, the aim of the government is to create people's welfare. Various legal rules in a democratic country are strived to the maximum extent possible for openness in the administration of government, this is intended to ensure that the course of government is always on the right track, namely to create people's welfare.

3. Power basically tends to be diverted. In general, abuse of power occurs and is increasingly rampant if there is no openness in governance. Therefore, democratic countries emphasize the importance of openness or transparency so that there is no abuse of power and bad governance. ${ }^{20}$

The principle of openness that must be carried out by the government does not mean that all information related to government administration can be accessed freely. There are, however, some exceptions to freedom of information or limitations on disclosure. This means that there are certain information limitations related to any implementation related to government. If there is information that is highly confidential and will cause problems, it certainly does not need to be known by the public or the press.

The principle of openness in the land acquisition process is closely related to community participation, therefore an open and transparent government must be able to guarantee community rights to land acquisition activities for development in the public interest, namely the right to monitor and observe land acquisition activities, the right to obtain information relating to land acquisition, the right to participate in the formation of policies related to land acquisition,

20 https://www.kompasiana.com, Pengertian dan Prinsip Keterbukaan (Definition and Principle of Openness), accessed on 10 June 2020. 
the right to be protected in relation to land acquisition and the right to raise objections. Therefore, disclosure of information related to land acquisition is to provide agrarian justice for the community whose goal is

1. Guarantee the rights of land owners to know the plan for making public land acquisition policies, land acquisition policy programs, and the land acquisition process and the objectives of land acquisition.

2. Encourage the participation of land owners in the land acquisition process to avoid land acquisition disputes.

3. Increase the active role of land owners in making policies related to land acquisition.

4. Realizing good state governance, namely one that is transparent, effective, efficient, accountable and accountable.

5. Knowing the reasons the government has procured land that will affect the lives of many people.

\section{E. Conclusion}

To realize agrarian justice, it is necessary for the state to ensure the principles of transparency both in at the level of regulation of land acquisition and its implementation as well. The principle of transparency in the land acquisition process is the human rights of land owners / holders and the general public. Therefore, it is the state's obligation to implement it in the land acquisition and avoid any causes that might lead to disputes. The principle of transparency is needed to facilitate the flow of community participation in development which is put into reality through an agreement between the government and land owners regarding the objectives of land acquisition, fair and proper compensation and the consequences and benefits of land acquisition for land owners.

\section{Bibliography}

\section{Legal Instruments}

Law Number 5 of 1960 on Basic Agrarian Law 
Law Number 2 of 2012 on Land Procurement

\section{Books}

Anggarlawa, Om Prakash, 1993, Compulsory Acquisition of Land In India Commentary On The Acquisition of Land Act, I of 1894, New Delhi India: The University Book Agency.

Ismaya, Samun, 2013, Hukum Administrasi Pertanahan (Land Administration Law), Yogyakarta, Graha Ilmu.

Mahendra, A.A. Oka 1996, Menguak Masalah Hukum, Demokrasi dan Pertanahan (Uncovering Legal, Democracy and Land Problems), Sinar Harapan, Cet pertama, Jakarta

Maria, SW, Sumardjono, June 2001, Kebijakan Pertanahan antara regulasi dan implementasi (Land Policy between regulation and implementation),Penerbit Buku Kompas, Jakarta.

Mertokoesoemo, Soedikno, 1985, Mengenal Hukum (Understanding the Law), Yogyakarta: Liberty.

Raharjo, Satjipto, 2000, Ilmu Hukum (Legal studies), PT Citra Aditya Bakti, Bandung.

Sumardjono, Maria SW, 2008. Tanah dalam Perspektif Hak Ekonomi, Sosial dan Budaya (Land in the Economic, Social and Cultural Rights Perspective) (Land Acquisition For Development in Public Interest (Problems and Alternative Solutions), Kompas Gramedia, Jakarta.

\section{Articles/Journals/Proceeding}

Febriananingsih, Nunuk, "Keterbukaan Informasi Publik Dalam Pemerintahan Menuju Tata Pemerintahan Yang Baik" (Public Information Openness in Governance Towards Good Governance), Jurnal Rechtsvinding, Vol I Nomor I, April 2012.

Hosen, M, et.al, "Asas-asas Hukum Perjanjian Pada pengadaan Tanah bagi Pembangunan Untuk Kepentingan Umum" (Contractual Legal Principles on Land acquisition for Development in Public Interest), Jurnal Hukum Progresif, Volume XIII/No. 2 / Desember 2019.

Jeany, Tabitha Sri, Pergeseran Konsep Kepentingan Umum dan Implikasinya Dalam Pengadaan Tanah di Indonesia (Shifting Concepts of 
Public Interest and Its Implications of Land Acquisition in Indonesia), Doctoral Thesis, Program Doktor Ilmu Hukum Univ Islam Indonesia, Yogyakarta, 2017.

Kristiyanto, Eko Noer, "Urgensi Keterbukaan Informasi Dalam Penyelenggaraan Pelayanan Publik" (The Urgency of Information Disclosure in Public Service Delivery), Jurnal Penelitian Hukum De Jure, Akreditasi LIPI: No:740 / AU/P2MI-LIPI/ 04/ 2016.

Mendel, Toby, Freedom of Information as an Internatonally Protectec $\mathrm{Hu}$ man Right, Article 19 (www.article 19.org,

Sahman, at. El, Permasalahan Hukum Pembebasan Tanah Untuk Kepentingan Pembangunan di Kab. Lombok Utara (Legal Issues on Land Acquisition for Development Interests in North Lombok Regency), Makalah, Kerjasama Pusrema dengan Bappeda KLU, 2012.

Sahman, at. El, "Penerapan Prinsip Keadilan Dalam Pembebasan Tanah Bagi Pembangunan Untuk Kepentingan Umum” (Application of the Justice Principle in Land Acquisition for Development for Public Interest), Jurnal IUS Vol. III No. 9, Desember 2015.

Sitorus, Oloan, Pengadaan tanah Untuk Pembangunan Bagi Kepentingan Umum (Permasalahan dan Alternatif solusi) (Land Acquisition For Development in Public Interest (Problems and Alternative Solutions), Proceeding of National Seminar, Problematika Pertanahan dan strategi penyelesaiannya, Cooperation between STPN Faculty of Law Trisakti University, Jakarta 7 October 2017.

Sufriadi, Yanto, Rekonstruksi Penyelesaian Sengketa Pengadaan Tanah Untuk Kepentingan Umum Dalam Perspektif Hukum Progresif (Studi Kasus Penyelesaian Sengketa Pengadaan Tanah Untuk Kepentingan Umum di Bengkulu) (Reconstruction of Land Acquisition Dispute Resolution for Public Interest in Progressive Legal Perspective (Case Study of Land Acquisition Dispute Resolution for Public Interest in Bengkulu)), Doctoral Thesis, Program Pascasarjana UNDIP, Semarang, 2011.

Wahanisa, Rofi, Politik Hukum Pengaturan Pengadaan Tanah Bagi Pembangunan Untuk Kepentingan Umum (Legal Politics of 
Land Acquisition Arrangements for Development in Public Interest), Proceeding of National Seminar, Cooperation between STPN and Pusat Studi Hukum Agraria, Jakarta 7 October 2017.

Yusrizal, Muhammad, "Perlindungan hukum pemegang hak atas tanah dalam pengadaan tanah untuk kepentingan umum" (Legal protection of land rights holders in land acquisition for public purposes), Jurnal De Lega Lata, Volume 2 Number 1, JanuaryJune 2017. 